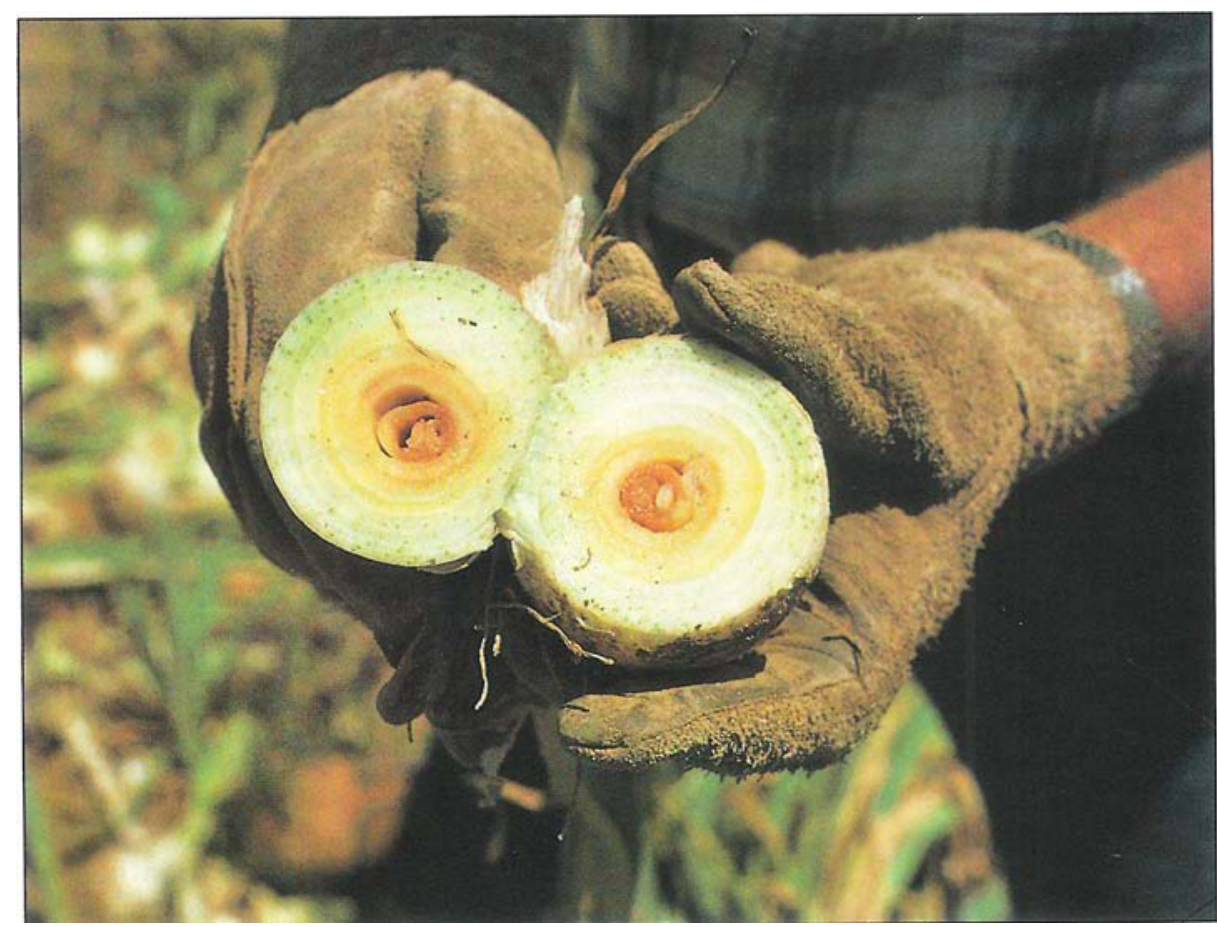

\section{Method of irrigation affects sour skin rot of onion}

\author{
Beth L. Teviotdale \\ 口 R. Michael Davis \\ - John P. Guerard
}

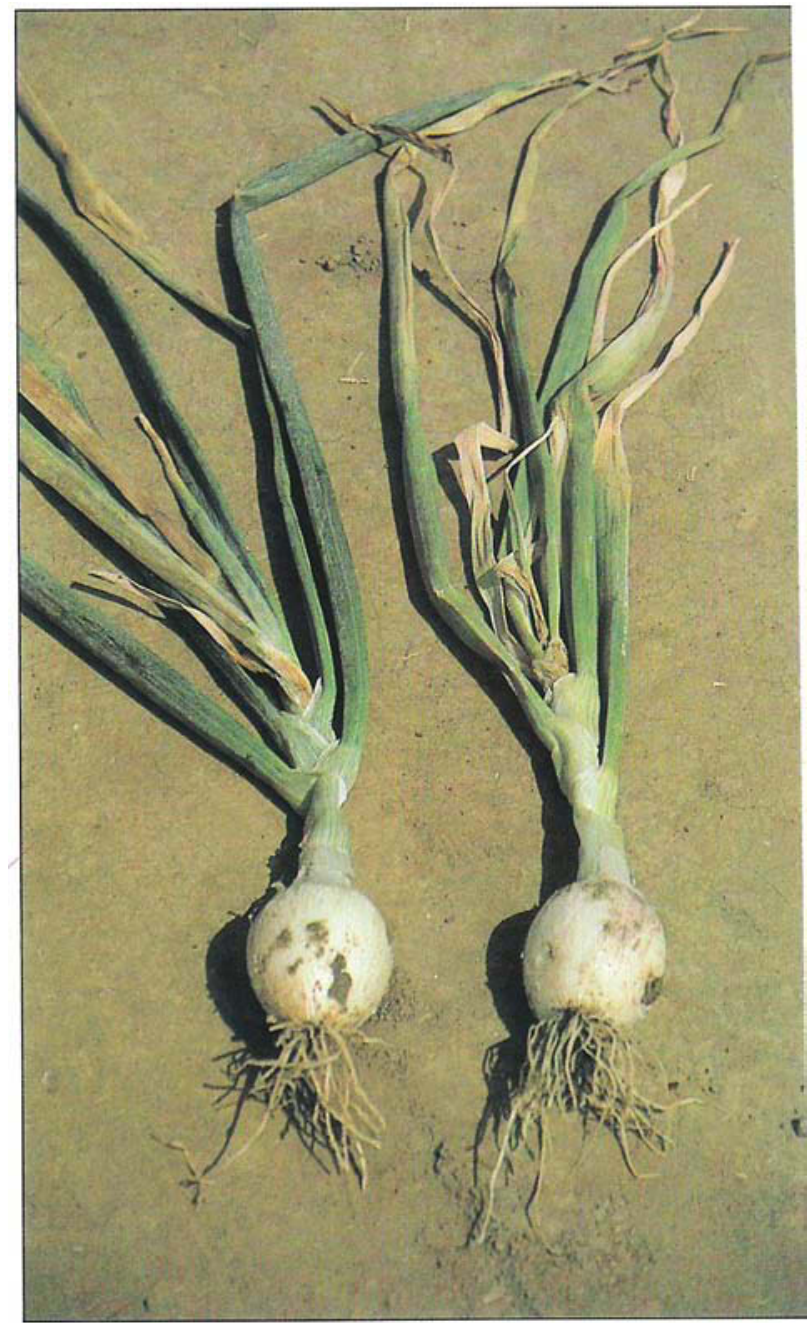

Onions irrigated by sprinkler too late in the season tend to develop sour skin rot. Affected leaves turn light brown and scales discolor and separate from healthy portions (above). When harvested, infected onions are rotted and discolored within (above lett).

replications of four irrigation regimes: furrow irrigation all season; sprinklerirrigation until bulbing and furrow irrigation for the remainder of the season; sprinkler irrigation to 30 days past bulbing and furrow irrigation for the remainder of the season; and sprinkler irrigation all season.

In this study, bulbing, which occurred in late May in both years, is defined as the time when the bulb diameter is about twice that of the neck. Each week included two 6-hour sprinkler sessions and one furrow irrigation. The final irrigation came in the first week in July each year.

The total seasonal water applications for treatments 1 through 4, including furrow irrigations, were 24.9, 24.3, 21.9, and 19.3 inches in 1987 and 38.0,37.2,36.5, and 36.0 inches in 1988. Variations in pump pressure and an increase in the number of irrigations because of weather conditions accounted for the differences in totals for the two years. 
Plots were centered between risers and located in the second beds on both sides of sprinkler lines and on the corresponding two beds in the furrow-irrigated sections. Both beds in each section were divided into 10-foot subplots, which were either inoculated or noninoculated. The inoculum consisted of a water suspension of $P$. cepacia, approximately 1 million bacteria per $\mathrm{ml}$, and was applied to runoff using a compressedair sprayer during two regularly scheduled sprinkler irrigations in the first and third weeks of June in both years.

Disease incidence was evaluated in midJuly. All bulbs in the subplots were cut just below the shoulder, and disease incidence was expressed as the percentage of bulbs with internal discoloration. Pseudomonas cepacia was recovered in culture from representative diseased bulbs.

Yield data were collected in August 1987 and July 1988. Fresh weights of all bulbs from 20 feet of the third (noninoculated) bed on both sides of the sprinkler line and the

TABLE 1. Effect of sprinkler and furrow irrigation
on sour skin rot incidence in onion, Fresno
County

TABLE 2. Yield of onions that were sprinkler-irrigated with three sizes of nozzle orifice, Kern County

Pounds fresh bulb weight per 10 feet $^{*}$

\begin{tabular}{|c|c|c|c|c|c|}
\hline \multirow{2}{*}{$\begin{array}{l}\text { Nozzle } \\
\text { orifice } \\
\text { diameter }\end{array}$} & \multirow[b]{2}{*}{1987} & \multirow[b]{2}{*}{1988} & \multicolumn{3}{|c|}{$1989 \dagger$} \\
\hline & & & A & B & C \\
\hline \multicolumn{6}{|l|}{ inches } \\
\hline $3 / 32$ & 51.4ał & $34.8 \mathrm{a}$ & $40.6 a$ & $24.9 a$ & 22.4 \\
\hline $7 / 64$ & $52.2 a$ & $38.7 a$ & $44.7 a$ & $32.2 b$ & $30.1 \mathrm{t}$ \\
\hline $1 / 8$ & $50.6 \mathrm{a}$ & $33.3 a$ & $45.9 a$ & $34.2 b$ & $33.2 t$ \\
\hline
\end{tabular}

Four replications of each treatment. Fresh market orions used in 1987, al' others are processing on ions.

tIdentical experiments located in three fields desig. nated $A, B$, and $C$

$¥$ Means tollowed by the same letter do not differ significantly according to Duncan's Multiple Range Test. $P=0.05$. corresponding beds in the furrow-irrigated plots were recorded in 1987. Identical measurements were taken from 10 feet per plot in 1988. The percentage of soluble solids in a sample of about 30 macerated onions taken from each plot was measured with a refractometer.

The incidence of sour skin was significantly less in the two treatments employing furrow irrigation for most or all of the season than in the two treatments irrigated by sprinkler for most or all of the season (table 1). The highest percentage of rot occurred in plots irrigated by sprinkler all season. Rot found in uninoculated checks was attributed to natural spread and infection.

There were no significant differences in fresh weight of bulbs or percentage soluble solids among the four irrigation systems in either year. Yields ranged from 2.8 to 3.4 and 5.9 to 6.6 pounds per bed foot in 1987 and 1988 , respectively. Percentage soluble solids varied from 22.5 to 23.7 in 1987 and 13.6 to 15.0 in 1988.

\section{Volume of overhead irrigation}

We tested the influence of variations in the amount of water applied by sprinklers on disease incidence and yield by altering the nozzle orifice size in five commercial onion fields. The experiment was conducted in fields of fresh-marketand processing onions in Kern County in 1987 and 1988, respectively, and in three fields of processing onions in 1989 in Fresno County. Plots were established between two adjacent sprinkler lines 16 beds apart.

Two opposite pairs of sprinklers, forming a square, were fitted with nozzles having orifices $3 / 32,7 / 64$, or $1 / 8$ inch in diameter. These nozzles delivered $0.10,0.20$, and 0.26 inches water per hour, respectively.

There were four replications of each treatment (each orifice size). Irrigation schedules varied, but most were every 4 to 7 days and 2 to 6 hours long.

One of the center beds in each plot was inoculated with P. cepacia as described above during regularly scheduled irrigations in June. Plots were inoculated twice in 1987 and 1988 and once in 1989. All bulbs in the center 10 feet of each inoculated bed in the 1987 Kern County trial and 100 bulbs in each plot in the other trials werecutand evaluated for disease in mid-July. Fresh weights of bulbs in 10 feet in each treatment were determined and soluble solids were measured as described above.

The volume of water delivered by the three nozzle orifice sizes increased with increasing orifice diameter. However, there was no correlation between the amount of water delivered and the percentage of rotted onions. The incidence of sour skin was low in four trials (less than $10 \%$ in all treatments), but high in the other trial $(63 \%$ in all treatments).
The fresh weight of bulbs was significantly lower in two experiments during 1989 in which onions were irrigated using $3 / 32$-inch nozzles than with either $7 / 64$ - or $1 / 8$-inch nozzles (table 2). No significant differences in the fresh weight of bulbs were found among treatments in the 1987 or 1988, or in one of the 1989 experiments. Percentage soluble solids was not affected significantly by the variable amounts of water in any trial.

\section{Conclusions}

Method of irrigation has a substantial impact on the incidence of sour skin of onions. Season-long overhead irrigation provided a favorable environment for sour skin rot, whereas furrow irrigation resulted in almost complete control of the disease. Only treatments in which sprinkler irrigation was used after bulbing resulted in high levels of the disease. The final four or five sprinkler irrigations were accompanied by a 150 to $300 \%$ increase in disease. Where sour skin is a potential problem, a change from sprinkler to furrow irrigation - at least from bulbing to the end of the season - is advisable.

The possibility that disease incidence could belowered by reducing the volume of water delivered was not substantiated by our experiments. Varying the amounts of water with different sizes of nozzle orifice did not reduce the incidence of sour skin in plotsirrigated with even thesmallest volume of water. Thus, growers opting for seasonlong overhead irrigation may not be able to reduce the volume of sprinkler irrigation enough to reduce disease while maintaining optimum yields.

Percentage soluble solids of the bulbs was not affected by differing amounts of water delivered by the three nozzle sizes. However, yield as measured by fresh weight of bulbs was reduced in two experiments in 1989 where the 3/32-inch-diameter orifice sprinklers were used. This may also have been true for the third 1989 experiment, but the test for significance failed by a slight margin.

The 3/32-inch nozzle size offers no advantage for disease control, and may be deleterious to yield. The $7 / 64$-inch nozzle appears to be a better choice than the $1 / 8$-inch nozzle because the former delivers significantly less water, but does not reduce the yield of fresh bulb weight or the percentage soluble solids content of bulbs.

Beth L. Teviotdale is Extension Plant Pathologist and Dennis H. Harper is StaffResearch Associate, Kearney Agricultural Center, Parlier; R. Michael Davis is Extension Plant Pathologist, Department of Plant Pathology, University of California, Davis; and John P. Guerard is Farm Advisor, UC Cooperative Extension, Kern County. This research was supported by a grant from the American Dehydrated Onion and Garlic Association. 